\title{
Н. Н. Малишевский
}

Республиканский институт высшей школы Белорусского государственного университета (Минск)

\section{Уроженцы белорусских земель Российской империи в Гражданской войне на востоке России}

\begin{abstract}
Статья посвящена представителям генералитета Белой армии - уроженцам белорусских земель Российской империи, имевшим белорусские корни и происхождение военачальникам, участвовавшим в белогвардейском движении и в Гражданской войне на востоке России. Рассматривается связь Белого движения и представителей его генералитета с Беларусью и дворянством белорусских губерний Российской империи, впервые названы поименно десятки военачальников-белорусов, имевших генеральские звания и сражавшихся в рядах Белой армии на востоке России. Делается вывод о малоосвещенности истории белорусов и уроженцев белорусской земли, сражавшихся в рядах белых, и необходимости изучения данной тематики.
\end{abstract}

Ключевые слова: Белая армия, уроженцы белорусских земель Российской империи, Гражданская война на востоке России.

стория белорусов и уроженцев белорусской земли, сражавшихся в рядах Белой армии, - одно из самых темных «пятен» в истории Гражданской войны. Если в России и Украине различным аспектам «белогвардейской» тематики посвящены десятки работ, то белорусские историки не спешат с вдумчивым анализом ситуации 100-летней давности. В профессиональном плане судьбами земляков-белогвардейцев никто не интересуется. На эту тему в Беларуси не опубликовано ни одного научного исследования. А ведь таких людей было не просто много, а очень много. Только в личном архиве (базе данных) автора настоящей статьи имеется более 20 тыс. биографий белорусов и уроженцев белорусской земли, сражавшихся в рядах Белой армии.

К тому же история Белого движения фактически началась на белорусской земле - в г. Быхов Могилевской губернии. Именно туда были доставлены зачинщики так называемого корниловского мятежа и Белого дела - генералы Л. Г. Корнилов, А. И. Деникин, С. Г. Марков, И. Г. Эрдели, А. С. Лукомский, И.П. Романовский и другие. Там, в Быховской женской гимназии, превращенной в тюрьму, они со- 
держались с сентября по ноябрь 1917 г. И именно из Быхова разными путями они отправились на Дон поднимать народ на борьбу против большевизма. Определение «быховец» было среди белогвардейцев очень почетным, означавшим, что человек стоял у самых истоков Белой борьбы в Гражданской войне, точкой отсчета которой можно считать опять же белорусский город Могилев, где 20 ноября [3 декабря] 1917 г. был убит исполнявший обязанности Верховного главнокомандующего Русской армией генерал-лейтенант Николай Николаевич Духонин.

На территории самой Беларуси боевых действий между «белыми» И «красными» и собственно «белых» воинских формирований почти не было. Отчасти исключением стали Отдельный Добровольческий корпус Северной армии и Пинско-Волынский добровольческий батальон, созданный на Пинщине в октябре 1918 г. под руководством уроженца Столинщины капитана императорской армии Антона Бохенского. Отдельный Добровольческий корпус формировался с сентября 1918 г. на Витебщине и Псковщине в качестве части русской Северной армии по инициативе русских офицеров и при поддержке Антанты (в первую очередь, для освобождения от большевиков Петрограда). Первоначально он находился под командованием белых генералов - уроженца минщины А. Е. Вандама (Едрихина), а затем уроженца могилевщины А. Ф. Дзерожинского. С декабря 1917 г. именовавшийся Северным корпусом, а с июня 1918 г. - Отдельным корпусом Северной армии, он позже вошел в состав Белой русской «непредрешенческой» Северо-Западной армии генерала от инфантерии Н.Н. Юденича.

В то же время белорусская земля дала Белой армии немало военачальников и генералов, сыгравших в Гражданской войне значительные роли. Например, крупной фигурой в Белом движении был уроженец Могилевской губернии Владимир Зенонович МайМаевский - один из ключевых стратегов Добровольческой армии генерала А.И. Деникина. Кстати, мать Деникина - Елизавета Францисковна Вжесинская происходила из обедневшего шляхетского рода, корни которого уходят в Речь Посполитую и Литовскую Русь. В. 3. Май-Маевский - герой русско-японской и Великой войн во время Гражданской войны возглавлял Добровольческую армию на пике ее успехов, когда белые взяли Орел и Курск и от Москвы их отделяло всего около ста верст. Также он был фактическим правителем всей подчиненной «белым» территории, включавшей большую часть Украины. В советское время образ Май-Маевского даже «лег в основу кино», став прототипом обаятельного генерала Ковалевского из сериала «Адъютант Его Превосходительства». 
Героями Белого движения были и белорусские мусульмане, кавалерийские начальники - генералы Михаил (Мустафа) Яковлевич Соболевский и Яков Давыдович Юзефович, родившийся и похороненный на Гродненщине. Причем его недавно обнаруженная могила является единственным из сохранившихся до наших дней на постсоветском пространстве захоронений руководителей Белой армии такого уровня.

Из дворян Минской губернии вел свой род сын офицера, казачий генерал-майор Константин Константинович Мамантов, командовавший знаменитым рейдом на Москву в 1919 г. Среди известных деятелей Белого движения, непосредственно связанных с Беларусью, можно назвать таких военачальников, как уроженца Гродно генерала Н. М. Киселевского, уроженца Минской губернии генерала А. К. Кельчевского, уроженца Витебской губернии, начальника контрразведки Русской армии в Крыму генерала Е.К. Климовича, уроженца Могилева генерала Б.И. Казановича и др.

Особо отметим генералов - уроженцев белорусских земель Российской империи, принявших участие в Гражданской войне в рядах Белой армий на востоке России, в губерниях наиболее отдаленных от Беларуси.

Одна из самых крупных фигур среди этих людей - герой сразу четырех славянских государств (России, Чехии, Беларуси и Словакии), уроженец Витебска генерал-майор Сергей Николаевич Войцеховский. Это имя в сегодняшней, очень далёкой от русофилии Праге знают намного лучше, чем в родной ему Беларуси и России. Чехи чтят память легендарного для них полководца. Его боевой опыт и политическую деятельность изучают в академиях. О нем выходят книги, статьи, репортажи. Ему устанавливают мемориальные доски и памятники (за свой и за государственный счет).

В российском блокбастере «Адмиралъ» есть волнующая сцена передачи умирающим генералом В. О. Каппелем командования генералу С.Н. Войцеховскому. В действительности, в отличие от киноперсонажа, которому явно за 50, реальный Войцеховский один из первых русских авиаторов, герой Мировой войны - был молод. В 1919 г. ему шел всего лишь 36-й год. При А. В. Колчаке он командовал 2-м Уфимским корпусом, а затем Дальневосточной русской армией. Именно он, ближайший соратник и преемник генерала Каппеля, сумел вывести остатки колчаковских войск в Забайкалье в феврале 1920 г. в невероятно тяжелых зимних условиях. Осенью того же года он руководил эвакуацией армии генерала П.Н. Врангеля. Действовал в тяжелейших условиях и вновь спас тысячи жизней. 
После Гражданской войны С.Н. Войцеховский переехал в Чехословакию, где занимал высокие военные посты, создавая в 1920-х 1930-х годах чехословацкую армию. Командовал столичным Пражским военным округом, в котором дислоцировались самые лучшие ее части. Генерал армии Чехословацкой Республики С. Н. Войцеховский - единственный представитель ее военно-политического руководства, который активно воспротивился сговору в Мюнхене. 26 сентября 1938 г. он создал для отражения агрессии нацистов специальную армейскую группировку. Форсировал строительство оборонительных сооружений вдоль чешско-германской границы. 30 сентября выступил на совещании у президента Чехословакии, доказывая, что можно противостоять агрессии гитлеровцев и сорвать Мюнхенский сговор. За это 1 апреля 1939 г. в возрасте неполных 56 лет был отправлен в отставку.

В условиях оккупации С.Н. Войцеховский создал и возглавил подпольную организацию Obrana národa («Защита народа»), входил в подпольное Чехословацкое правительство и занимал в нем пост военного министра. В сентябре 1939 г. был арестован Гестапо. Всю войну находился под наблюдением спецслужб Рейха. 12 мая 1945 г. органы СМЕРШ выкрали С.Н. Войцеховского из Праги. Однако вместо расстрела или повешения его приговорили к 10 годам заключения за «колчаковское» прошлое. В ГУЛАГе судьба опять вернула генерала в те места, где он сражался в Гражданскую войну. Круг замкнулся: если и была его вина в том, что он воевал против соотечественников, искупил он ее сполна, умерев в лагере незадолго до освобождения. В 1997 г. президент Чехии Вацлав Гавел посмертно наградил С. Н. Войцеховского орденом Белого Льва как национального героя Чехии.

Участниками Белого движения на востоке России после октябрьского переворота стали и два генерала, полных тезки. Первый - Михаил Михайлович Плешков-старший, один из немногих военачальников с белорусскими корнями, имевших к началу Мировой войны высший чин полного генерала ${ }^{1}$. Второй - его сын, родившийся в 1885 г. в г. Белосток Гродненской губернии. В современных энциклопедиях их обычно относят к потомственным дворянам Могилевской губернии ${ }^{2}$, хотя в предисловии к мемуарам М. М. Плешковамладшего, увидевшим свет в 1959 г. в Мюнхене, указано, что Плешковы ведут свой род из дворян Витебской губернии ${ }^{3}$.

${ }^{1}$ Бондаренко В. Полководцы и военачальники Первой мировой войны - уроженцы Беларуси. Минск, 2014. С. 76.

${ }^{2}$ Купцов И.В., Буяков А.М., Юшко В.Л. Белый генералитет на Востоке России в годы Гражданской войны. Биографический справочник. М., 2011. С. 418.

${ }^{3}$ Плешков М.М. Мои воспоминания. Мюнхен, 1959. С. 3. 
В 1918 г. М.М. Плешков-старший уехал на Дальний Восток, где принял участие в Гражданской войне. Совместно с генералом Д. Л. Хорватом он занимался формированием вооруженных отрядов Добровольческой армии Дальнего Востока как военный глава Харбина, начальник русских войск и главноначальствующий в полосе отчуждения Китайско-Восточной железной дороги. 23 и 24 августа 1918 г., являясь по соглашению с правительством П. Я. Дербера - И. А. Лаврова главнокомандующим войсками на российском Дальнем Востоке и имея пост начальника русских войск в полосе отчуждения КВЖД (при нем состоял штаб отдельного корпуса), руководил попыткой вооруженного переворота во Владивостоке. Был близок к адмиралу А.В. Колчаку, участвовал вместе с сыном (полковником, затем генерал-майором Белой армии) в сражениях на Восточном фронте Гражданской войны.

В белорусских энциклопедиях и ведущих энциклопедических изданиях как советского ${ }^{4}$, так и постсоветского ${ }^{5}$ времени в качестве военачальника, имеющего белорусские корни, фигурирует человек удивительной судьбы - уроженец Санкт-Петербурга Аполлон Яковлевич Крузе (Крусс), сумевший получить генеральское звание дважды. Первый раз он стал генерал-майором в 1919 г. «за отличия» в Белой армии адмирала А. В. Колчака, исполняя должность начальника штаба Южной группы войск Сибирской армии, а затем начальника штаба Южной группы генерал-лейтенанта Г. А. Вержбицкого в составе 2-й армии белых. Во второй раз он получил чин генерал-майора в 1943 г., исполняя должность начальника штаба Сталинградской группы войск Красной армии. Закончил Великую Отечественную войну бывший «белый» генерал Крузе во главе героического 24-го Братиславского стрелкового корпуса Красной армии, освобождавшего от фашистов Словакию и отличившегося при освобождении Братиславы, а в 1949 г. стал генерал-лейтенантом. Несмотря на полтора года непрерывной борьбы против большевиков на Восточном фронте, в СССР он никогда не подвергался репрессиям. Более того, в 1939 г. был принят в коммунистическую партию.

В целом из 728 представителей «белого» генералитета на востоке России в годы Гражданской войны, известных российским авторам ${ }^{6}$, уроженцами и представителями дворянства белорусских губерний

4 Белорусская ССР: Краткая энциклопедия: В 5-и томах / редкол.: И. П. Шамякин (гл. ред.) [и др.]. Минск, 1981. Т. 5: Биографический справочник. С. 335.

5 Энцыклапедыя гісторыі Беларусі: У 6 т. Т. 4: Кадэты-Ляшчэня / Беларус. энцыкл. Рэдкал. Г. П. Пашкоу (гал. рэд.) і інш. Мінск, 1997. С. 264; Беларуская энцыклапедыя: У 18 т. Т. 8: Канто-Кулі / рэдкал. Г.П. Пашкоу і інш. Мінск, 1999. С. 484.

${ }^{6}$ Купцов И. В., Буяков А.М., Юшко В.Л. Белый генералитет на Востоке России... С. 4. 
были не менее 30. Многие офицеры и генералы, участники Белого движения на востоке России, являлись выпускниками белорусских учебных заведений (например, генерал-майор С. И. Бруевич окончил Могилевскую духовную семинарию, генерал-майор Е. К. Вишневский - Брест-Литовскую прогимназию), и прежде всего - знаменитого Полоцкого кадетского корпуса. Полоцкими кадетами были генерал-майор Евгений Александрович Слешинский, генерал-майор Аркадий Павлович Слижиков, генерал-майор Константин Георгиевич Тарнопольский, генерал от инфантерии Евгений Евгеньевич Уссаковский, представитель дворянского рода, восходящего к белорусскому (русско-литовскому) рыцарству XV века, генерал-лейтенант Алексей Николаевич Бунин, генерал-майор Владимир Александрович Правиков, генерал-майор Владимир Константинович Семигановский, генерал-майор Владимир Иванович Зенкевич.

Больше всего генералов восточным формированиям Белой армии дала Минская губерния. В их числе генерал-майор Иван Никифорович Шиц, уроженец Минска генерал-майор Константин Георгиевич Тарнопольский, уроженец г. Мозырь Минской губернии генерал-майор Ипполит Ермолаевич Барановский, уроженец г. Бобруйск Минской губернии генерал-майор Николай (Бронислав) Львович Забелло, уроженцы г. Слуцк Минской губернии генерал-майор Павел Семенович Максимо́вич и генерал-майор Константин Константинович Никитин. Из дворян Минской губернии происходили также генерал-майор Лев Михайлович Адамович и генерал-майор Болеслав Яковлевич Мощинский.

В семье потомственных дворян Минской губернии родился и контр-адмирал Борис Андреевич Вилькицкий, получивший этот чин в рядах Белой армии 16 октября 1919 г., находясь в подчинении у адмирала А.В. Колчака ${ }^{7}$. Еще одним моряком-белогвардейцем, служившим в рядах Белой армии на востоке России, был уроженец Минщины генерал-майор флота Михаил Николаевич Большев.

Могилевская губерния - родина генерал-майора Степана Ивановича Бруевича, генерал-лейтенанта Александра Ивановича ИпатовичГоранского, генерал-майора Евгения Александровича Слешинского, генерала от инфантерии Евгения Евгеньевича Уссаковского, генерал-майора Аркадия Павловича Слижикова. Из дворян Могилевской губернии происходил также генерал-лейтенант Антон Викентьевич Бордзиловский.

Город Витебск дал «белым» армиям востока России, помимо С.Н. Войцеховского, еще трех генералов: генерал-майора Констан-

7 Там же. С. 103, 104. 
тина Макаровича Ткачева, генерал-лейтенанта Алексея Григорьевича Гибер фон Грейфенфельса и генерал-майора Виктора Ивановича Гибер фон Грейфенфельса. Из потомственных дворян Витебской губернии были также генерал-майор Генрих Антонович Правохенский, генерал-майор Леонид Николаевич Скипетров, генерал-майор Владимир Иванович Зенкевич.

Из потомственных дворян Гродненской губернии происходили генерал-майор Николай Константинович Боровский, генерал-майор Казимир Александрович Высоцкий, уроженец г. Гродно Адам Адамович Бояровский и уроженец г. Брест-Литовск Гродненской губернии генерал-майор Евгений Кондратьевич Вишневский.

Обо всех этих и еще тысячах людей - уроженцах белорусских земель Российской империи, принявших участие в Гражданской войне на востоке России в рядах Белой армии, - сегодня у них на родине не принято ни вспоминать, ни писать, будто их никогда и не было. В советские времена они проходили по категории «враги народа». Действительно, Гражданская война - это всегда трагедия. Трагедия общества, которое продолжает делить и делиться на «врагов» и «своих», когда нужно объединять и объединяться. Но это трагедия не только общественная. Это трагедия и личная, и семейная. И все участники и стороны в ней - и «белые», и «красные» - все наши. Их можно не понимать, не разделять взгляды или идеи, но принять как историческую данность и изучать то, что им пришлось пережить, можно и нужно. 